\title{
Alopecic and Aseptic Nodules of the Scalp: First Report in South America and Second in America
}

\author{
Cristián Fischer-Levancini $^{a} \quad$ Matías Gompertz ${ }^{b}$ Antonio Guglielmettic \\ Héctor Opazo ${ }^{d}$ \\ ${ }^{a}$ Department of Dermatology, Hospital Universitari Sagrat Cor Barcelona, Barcelona, Spain; ${ }^{b}$ Department of \\ Dermatology, Faculty of Medicine, Pontificia Universidad Católica de Chile, Santiago, and Departments of \\ 'Dermatology and ${ }^{\mathrm{d}}$ Pathology, University of Valparaíso, Valparaíso, Chile
}

\section{Established Facts}

- Aseptic and alopecic nodules of the scalp are a rare disease, which is in most of the cases diagnosed in Asian and Caucasian populations.

- The diagnosis requires a high level of suspicion and is confirmed by histopathological findings.

\section{Novel Insights}

- After reviewing all published cases, we propose that doxycycline $100 \mathrm{mg}$ per day for $1-3 \mathrm{months}$ should be considered as the first line of treatment. If no response is obtained, intralesional injection of corticoids should be attempted. The disappearance of the nodule is fast but hair takes time to regrow.

\section{Keywords}

Alopecic and aseptic nodules of the scalp - Pseudocyst of the scalp · Alopecia

\begin{abstract}
Alopecic and aseptic nodules of the scalp, also named pseudocysts of the scalp, are a relatively new, little-known, and for sure underdiagnosed disease. It affects mostly young men and is characterized by a solitary or a few dome-shaped nodules accompanied by nonscarring alopecia, deep inflammatory infiltration in the skin biopsy specimen, and, in most cases, granulomas. It has a good response to doxycycline,
\end{abstract}

intralesional corticosteroids, or drainage/aspiration of the lesion. We present a case report and a summary of the published cases.

(c) 2017 S. Karger AG, Basel

\section{KARGER}

(c) 2017 S. Karger AG, Basel

E-Mail karger@karger.com

www.karger.com/sad

\section{Introduction}

Aseptic and alopecic nodules of the scalp (AANS), also named pseudocysts of the scalp, are a new, little-known, and for sure underdiagnosed disease [1]. AANS were first described in Japanese publications in 1992 [1] and were first named as pseudocysts of the scalp because cystic cav- 
Table 1. Summary of the main characteristics of all the cases described in the literature

\begin{tabular}{|c|c|c|c|c|c|c|c|c|}
\hline $\begin{array}{l}\text { Authors } \\
\text { [Ref.], year }\end{array}$ & $\begin{array}{l}\text { Cases, } \\
n\end{array}$ & $\begin{array}{l}\text { Age, } \\
\text { years }\end{array}$ & $\begin{array}{l}\text { Gender } \\
(\mathrm{M}: \mathrm{F})\end{array}$ & Ethnicity & $\begin{array}{l}\text { Number of } \\
\text { nodules }\end{array}$ & Localization & Histopathology & Treatment \\
\hline $\begin{array}{l}\text { Iwata et al. } \\
{[2], 1992}\end{array}$ & 19 & $18-40$ & $14: 5$ & Asian & 1 & $\begin{array}{l}\text { Parietal and } \\
\text { frontal }\end{array}$ & Pseudocyst and granuloma & $\begin{array}{l}\text { Aspiration }+ \\
\text { intralesional corticoid } \\
\text { injection }(10 / 19)\end{array}$ \\
\hline $\begin{array}{l}\text { Chevallier } \\
{[3], 1998}\end{array}$ & 3 & $17-35$ & $2: 1$ & Caucasic & 1 & N/A & $\begin{array}{l}\text { Follicular cyst and } \\
\text { granuloma }\end{array}$ & Repetitive punctures \\
\hline $\begin{array}{l}\text { Tsuruta } \\
{[11], 2009}\end{array}$ & 2 & 15,36 & $1: 1$ & Asian & 5,3 & N/A & N/A & $\begin{array}{l}\text { Resolution after } \\
\text { biopsy (1), } \\
\text { intralesional corticoid } \\
\text { injection (1) }\end{array}$ \\
\hline $\begin{array}{l}\text { Lee et al. } \\
\text { [8], } 2011\end{array}$ & 1 & 72 & $0: 1$ & Asian & 1 & Temporal & Pseudocyst-like & Surgical excision \\
\hline $\begin{array}{l}\text { Eisenberg } \\
{[6], 2012}\end{array}$ & 11 & $16-48$ & $3: 8$ & $\begin{array}{l}\text { Caucasic: } 5 \\
\text { Hispanic: } 1 \\
\text { Arab: } 2 \\
\text { Black: } 2 \\
\text { Asian: } 1\end{array}$ & $\begin{aligned} 10 & =1 \text { nodule } \\
2 & =2 \text { nodules }\end{aligned}$ & $\begin{array}{l}\text { Vertex (10) and } \\
\text { occipital (1) }\end{array}$ & N/A & $\begin{array}{l}\text { Puncture and } \\
\text { intralesional corticoid } \\
\text { injection } \\
\text { (triamcinolone } \\
\text { acetonide } 2.5 \mathrm{mg} / \mathrm{mL} \text { ) }\end{array}$ \\
\hline
\end{tabular}

M, male; F, female; N/A, not available. There are 3 published articles in the Japanese literature, whose full texts are not available [13-15].

ities with no real cystic wall were found in the histopathologic study [2]. The first cases in Western populations were described in France by Chevallier [3] in 1998, who called them "non-infectious abscesses and balding scalp." It was not until 2009, when Abdennader et al. [4, 5] introduced the name "aseptic and alopecic scalp nodules," because they did not find the cystic cavities in all of their cases as the Japanese did. To this date, there are only 86 published cases (summarized in Table 1), with only one report of cases from North America [6] and none from South America.

Alopecic and Aseptic Nodules of the Scalp

\section{Case Report}

A 34-year-old man with no previous medical history presented with a 2-month history of an asymptomatic and alopecic plaque on the vertex of his head. On the exam, two soft and dome-shaped nodules of $3 \mathrm{~cm}$ in diameter, slightly erythematous and alopecic on its surface and surrounded by normal scalp were seen (Fig. 1). Citrine exudate was obtained in the puncture. The biopsy showed at the superficial and deep dermis a chronic inflammatory process and deep chronic folliculitis (Fig. 2). Specific stains ruled out bacteria and fungi. He received doxycycline $100 \mathrm{mg}$ per day for 8 weeks achieving complete remission, without relapses in 18 months of follow-up (Fig. 3). 


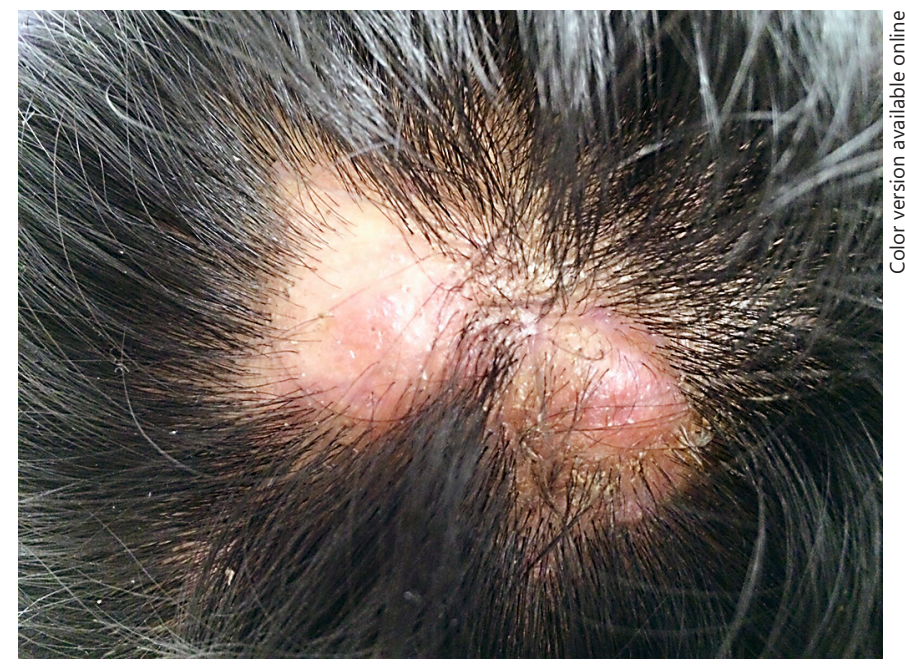

Fig. 1. Two soft and dome-shaped nodules, slightly erythematous and alopecic on its surface, surrounded by normal scalp.

\section{Discussion}

As can be seen in Table 1, this entity affects mainly men $(77.9 \%)$ at young ages (generally between 11 and 40 years) and presents as one or two (94\%) alopecic and dome-shaped nodules with normal surrounding skin, usually asymptomatic or with occasional discomfort. Most of the cases reported are from Asian (44.2\%) or Caucasic (43\%) patients, while other ethnicities are infrequent. The consistency of the nodule can be firm or fluctuating [7]. Hair loss occurs in an early phase coinciding with the formation of the nodule, healing without scarring alopecia. They are located predominantly at the level of the vertex followed by occipital and parietal regions, although any area of the scalp can be affected. They are typically an isolated event but in some cases tend to recur [6].

When the nodule is punctured, the material obtained can be serous, yellowish, or purulent depending on the characteristics of the infiltrate and type of vessel compromised by the infiltrate. It will be citrine yellow in case of a lymphatic vessel, pink glassy in blood vessel, or purulent in case of a polymorphonuclear infiltrate $[1,4]$. Cultures are negative in all cases described [7].

In the skin biopsy, these nodules present mixed inflammatory infiltrate (lymphocytes, histiocytes, and giant cells) and in most cases also granulomas in the deep dermis or architecture as pseudocyst with no real wall. The histological differences are believed to be due to racial

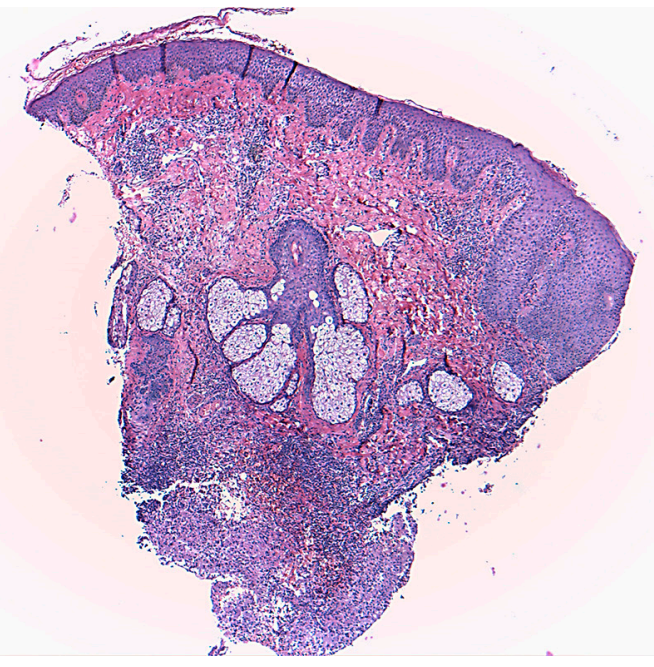

Fig. 2. Hematoxylin and eosin staining. Superficial and deep perivascular mixed inflammation and deep chronic folliculitis.

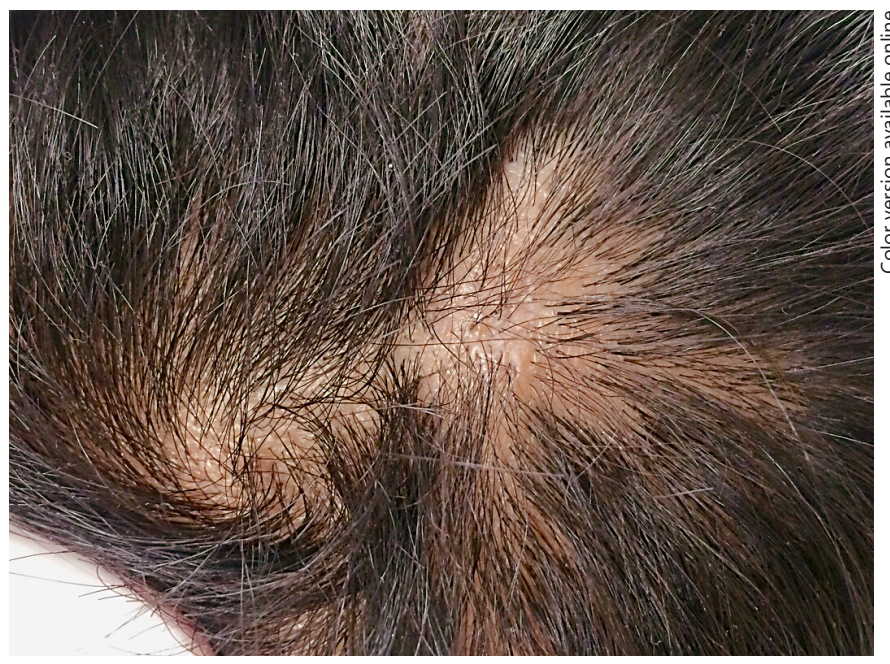

Fig. 3. Eighteen weeks after finishing doxycycline. Note the disappearance of nodules and hair growth.

factors of hair type or because of superficial samples [5]. Seol et al. [7] consider that pseudocyst formation seems to be a secondary change to inflammation and can also be influenced by the severity of duration of inflammation, the mean duration was longer for patients with than without pseudocyst formation in their study.

AANS respond well to treatment with doxycycline 100 mg per day with no established duration, usually for 1-3
Fischer-Levancini/Gompertz/ Guglielmetti/Opazo 
months [5, 7], intralesional corticosteroids $[6,7]$, or drainage/aspiration of the lesion as summarized in $\mathrm{Ta}$ ble $1[3,7]$. Spontaneous regression has been reported; thus, surgical excision is not necessary.

The etiology is unknown; it is considered a type of deep folliculitis associated with follicular occlusion or foreign body reaction. There is a granulomatous reaction with inflammatory infiltrate composed of lymphocytes, histiocytes, and giant cells, with subsequent central necrosis and erosion of blood and lymph vessels, causing the exudate and pseudocyst formation. Some authors mention that this entity could be within the spectrum of diseases associated with follicular occlusion, although an immunological process could not be excluded $[4,7,8]$. The differential diagnosis should be made with superinfected trichilemmal cyst, alopecia areata, bacterial or dermatophytic folliculitis, cutaneous metastasis, and dissecting cellulitis. The latter, unlike AANS, presents clinically as multiple erythematous and painful nodules, forming abscesses and fistulas causing scarring alopecia [9].

We agree with Abdennader et al. [5] and Seol et al. [7] that AANS and scalp pseudocysts are likely to be the same entity with a varied histopathologic spectrum rather than different diseases. The first is a more appropriate name because the nodules are always alopecic, the material obtained by puncture is sterile, and the histopathological study pseudocysts are not always found [5]. However, Lee et al. [8] think that they are two different conditions based on the presence of pseudocysts, which are absent in the first one and present in the second.

Our patient represents the first case of AANS reported in South America, the second in America, and the fourth of Hispanic ethnicity. When we controlled the patient after the 8-week course of doxycycline, we observed a quick disappearance of the nodule but persistence of nonscarring alopecia. In the next few months, hair started to grow until full healing was achieved. This also happened in another case treated by one of the authors. Thus, it is relevant to warn the patient that the clinical response of the nodule and hair are different, so that he does not consider it a therapeutic failure. After reviewing all the published data, we propose doxycycline $100 \mathrm{mg}$ per day for 2-3 months as the first therapeutic option, avoiding the pain of intralesional injections. If no response is obtained, intralesional injection of corticoids should be attempted.

In conclusion, AANS constitute an emerging entity in the literature, probably underdiagnosed because of its ignorance. It is diagnosed by the presence of alopecic nodules on the scalp without scarring alopecia and with aseptic content. It generally behaves as an easy-to-handle disease with good response to treatment with doxycycline. Is necessary to know this entity to treat properly and avoid unnecessary harm.

\section{Statement of Ethics}

The patient was seen in a private practice; thus, the approval from the institute's committee on human research does not apply. The patient consented to the publication of his case.

\section{Disclosure Statement}

The authors have no conflicts of interest to disclose and no fundings to report.

\section{References}

1 Fischer-Levancini C, Iglesias-Sancho M, Collgros H, Sánchez-Regaña M: Aseptic and alopecic nodules of the scalp. Actas Dermosifilogr 2014;105:208-211.

2 Iwata T, Hashimoto T, Niimura M: A pseudocyst with inflammatory granulation tissue on scalp - pseudocyst of scalp. Jpn J Clin Dermatol 1992;46:9-16.

3 Chevallier J: Abcès non infectieux et alopéciques du cuir chevelu: nouvelle entité? Nouv Dermatol 1998;17:181.

4 Abdennader S, Reygagne P: Alopecic and aseptic nodules of the scalp. Dermatology 2009;218:86.

5 Abdennader S, Vignon-Pennamen MD, Hatchuel J, Reygagne P: Alopecic and aseptic nodules of the scalp (pseudocyst of the scalp): a prospective clinicopathological study of 15 cases. Dermatology 2011;222:31-35.
6 Eisenberg EL: Alopecia-associated pseudocyst of the scalp. J Am Acad Dermatol 2012; 67:114-116.

7 Seol JE, Park IH, Kim DH, et al: Alopecic and aseptic nodules of the scalp/pseudocyst of the scalp: clinicopathological and therapeutic analyses in 11 Korean patients. Dermatology 2016;232:165-170.

8 Lee SS, Kim SY, Im M, et al: Pseudocyst of the scalp. Ann Dermatol 2011;23:267-269.

9 Gutierrez Rodriguez MC, Marino Harrison JM: Nódulos inflamatorios y alopecia en el cuero cabelludo. Piel 2003;18:270-272.

10 Tsuruta D, Hayashi A, Kobayashi H, et al: Pseudocyst of the scalp. Dermatology 2005; 210:333-335.
11 Tsuruta D: Reply letter. Dermatology 2009; 218:87.

12 Gargallo A, García O, Molina E, Schoendorff C: Alopecic and aseptic nodules of the scalp. J Am Acad Dermatol 2015;72:AB110.

13 Nukaga Y, Matsuura K, Matsushima Y: A case of pseudocyst of the scalp. Hifu Rinsho (Tokyo) 1995;37:1772-1773.

14 Shibagaki N, Sugiyama H, Ohtake N, Furue M, Shimada S: Analysis of 3 cases of inflammatory granulomatous nodule with pseudocyst associated with follicular occlusion triad - pseudocystic granuloma of skin. Jpn J Clin Dermatol 1996;50:105-110.

15 Aiba S, Mukai H: Pseudocyst of the scalp. Pract Dermatol 2002;24:893-896. 